\title{
OBSERVATIONS OF SELECTED TRUE BUGS \\ (HEMIPTERA: HETEROPTERA) OF THE PACIFIC NORTHWEST SHRUB-STEPPE ZONE
}

\author{
John D. Lattin ${ }^{1}$
}

\begin{abstract}
Key words: Pacific Northwest, Hemiptera, Heteroptera, Miridae, Labops, Myrmecophyes, Tingidae, Acalypta, host plants.
\end{abstract}

The shrub-steppe zone of the Pacific Northwest extends over a vast interior region. Bailey (1998) published a broadscale treatment of the ecoregions of the world, complete with a detailed map. Much of western North America is included in the Temperate Steppe Division, Temperate Steppe Regime Mountains, and the Temperate Desert Division. Houghton (1986) provided an account of the Great Basin that includes parts of California, Idaho, Nevada, Oregon, and Utah. Franklin and Dyrness (1988) included the Columbia Basin, the High Lava Plains, the Owyhee Upland, and the Basin and Range as physiographic and geological provinces of Oregon and Washington. Thorson et al. (2003) published a detailed map of the ecoregions of Oregon where most of eastern Oregon was encompassed in the Columbia Plateau, Blue Mountains, Cascades Slopes and Foothills, and northern Basin and Range. The Columbia River basin includes portions of Idaho, California, Nevada, and Oregon (Lattin 1995).

A number of plants in the Pacific Northwest shrub-steppe zone respond early in the season when moisture is limited. Early season temperatures, near freezing at night and in early morning, warm gradually as the season progresses. Insects adapted to feed on such plants must cope with the lower temperatures and respond to the early pulse of new growth. Knowledge of insects characteristic of shrubsteppe habitats is still rather sparse, even though these organisms surely exhibit greater species diversity than any other group in this region. Many plant taxa are broadly distributed in this zone (Franklin and Dyrness 1988), for example,
Artemesia and Purshia. While little is known about the distribution and habits of most insects and mites found on these plants, Kraft (1960) cited more than 250 species he collected on bitterbrush, Purshia tridentata (Pursh.) DC., in portions of the shrub-steppe in the Pacific Northwest during 1957 and 1958. Lattin (1995) estimated that 30 families, 163 genera, and 307 species of true bugs (Hemiptera: Heteroptera) occurred in the Columbia River basin area encompassing several states and extensive areas of shrub-steppe habitats. The variety of introduced plants (accidental and deliberate) has adversely affected native plants, while some have been colonized and injured by native bug species, for example, black grass bugs on introduced Agropyron species.

Many species of true bugs use these early maturing plants. Since they often occur before most field work begins, several species of true bugs remain to be discovered. Some of these species belong to genera that are also represented in Central Asia but are represented only by a single species in northwestern North America. Two of the species reported here are found in both regions.

\section{Miridae}

Several genera of plant bugs found in the shrub-steppe contain species that are adapted to plants that mature in early spring. The first occurrence of the Old World mirid genus Myrmecophyes Fieber in North America was based upon specimens collected in eastern Oregon (Schuh and Lattin 1980). This minute

${ }^{1}$ Rice Professor of Systematic Entomology (Emeritus), Department of Botany and Plant Pathology, Oregon State University, Corvallis, OR 97331-2902. 
but striking insect (Fig. 1) was found on early maturing native grasses near the city of Burns. Whereas some Old World species of this genus occur as short- and long-winged individuals (Drapolyuk 1989), only short-winged specimens of M. oregonensis Schuh and Lattin have been collected. Known only from eastern Oregon, it is likely to be found at other localities in western North America.

The plant bug genus Labops Burmeister is found throughout the upper portions of the northern hemisphere, with representation in northeastern Siberia and northwestern North America (Slater 1954). Eight species are found in North America whereas 1 species, L. burmeisteri Stål, occurs in northwestern Canada, Alaska, and Siberia. Labops tumidifrons Knight (Fig. 2) is widely distributed in western Canada and portions of the United States but is known only from a few localities. In central Oregon near LaPine, numerous specimens were taken on Carex douglasii Boott in a moist habitat among scattered lodgepole pine (Pinus contorta Dougl. ex. Loud.). The nearest previously known locality was Chilcotin, British Columbia, hundreds of kilometers to the north.

Labops species native to North America are of special interest because several have become serious pests on range grasses, particularly nonnative crested wheatgrasses introduced for range improvement (Lattin et al. 1994, 1995). It is not surprising that native Labops species moved onto these grasses, because at least 1 Labops species feeds on crested wheatgrasses in Central Asia where these grasses are native. Review of the literature before the introduction of crested wheatgrasses to North America would have disclosed that host association, perhaps influencing the decision to introduce the plants.

\section{TingIDAE}

Acalypta cooleyi Drake (Fig. 3) is a small lace bug belonging to a genus found throughout the north temperate region (Drake and Lattin 1963, Golub 1973, Froeschner 1976). Where known, the various Acalypta species are found on mosses (Drake and Lattin 1963, Froeschner 1976, Scudder 1997). It was a surprise to find specimens of A. cooleyi in eastern Oregon near Burns. However, a moss, Tortula ruralis (Hedw.) Gaertn. et al., does occur around the bases of shrubs in the area. The lace bug was described from Bozeman, Montana, by Drake (1917). Drake and Lattin (1963) reported it from Pinehurst, Oregon, and Sequoia National Forest, California; Froeschner (1976) recorded it near Holbrook, Arizona; and Scudder (1997) reported it from the Yukon. Golub (1973) cited this species from Irkutsk, Kazakhstan, and the Amur district of Central Asia. These latter records extend the range of $A$. cooleyi considerably and demonstrate some of the close faunal relationships between the Pacific Northwest and Siberia. Another example is the recently reported Palearctic anthocorid Scoloposcellis pulchella pulchella (Zetterstedt) from east central Alaska (Lattin 2005).

Extensive grazing of cattle has also affected the native fauna and flora. The insect species discussed here are examples of the nonnative introductions to North America. Many more are certain to be found. Better knowledge of various insect species, their host plants, and distributions will be valuable to those responsible for long-term management of these important plant resources.

\section{CONCLUSIONS}

The true bug fauna (Hemiptera: Heteroptera), estimated at 800 species (Lattin unpublished data), is well represented in the Pacific Northwest. While occurrence and distribution of many of these species are well known for the mesic portions of this vast region, relatively little is known about many of the bugs in the drier shrub-steppe zone. Except for works by Kraft (1960) and Lattin (1995), there is much to learn about the bug fauna of this zone. Several interesting species found in the shrubsteppe zone are presented here. Two of these also occur in the eastern Palearctic Region of the Old World, indicating faunal similarities between these 2 areas. Much of western North America has been affected by agriculture and grazing, and better knowledge of the insect fauna will be important in reaching reasonable solutions to land management.

My thanks to the late B. Hall for the fine drawings, A. Christie and 2 reviewers for comments on the manuscript, and L. Parks for careful attention to the manuscript. Specimens are housed in the collection of the Oregon State University Entomology Museum, Corvallis. 


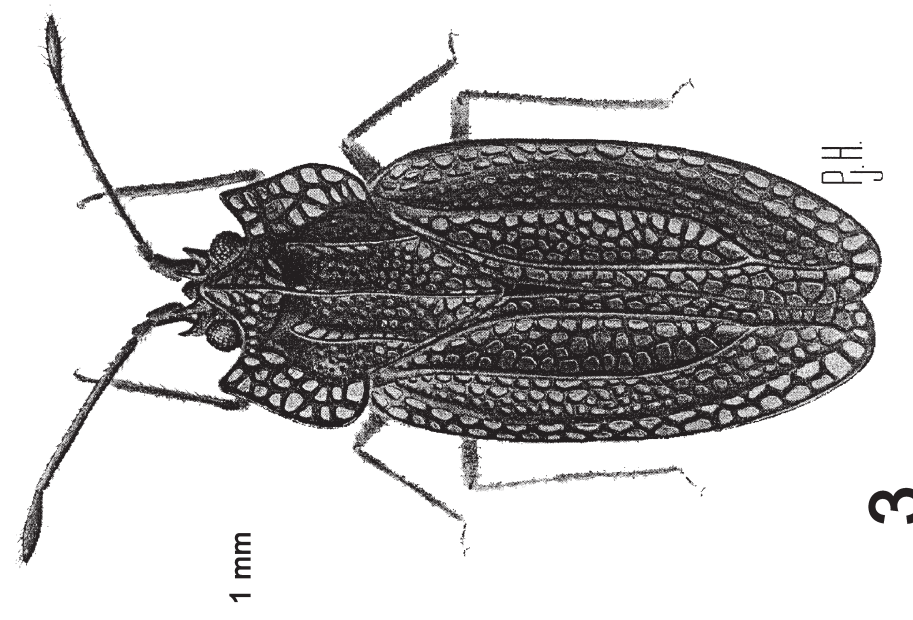

d
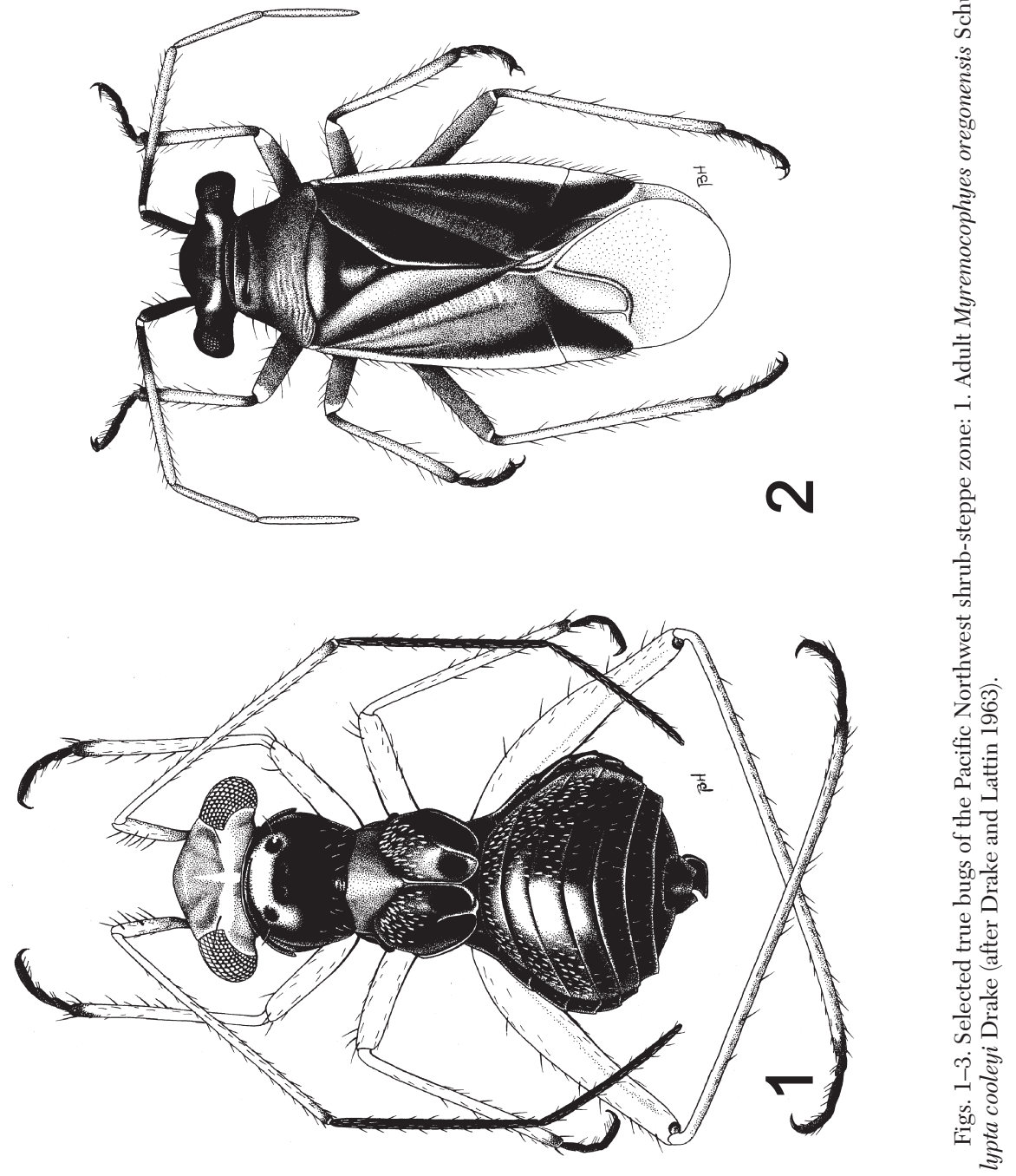


\section{Literature Cited}

BAILEY, R.G. 1998. Ecoregions. Springer, New York. 176 pp. Drake, C.J. 1917. New and noteworthy Tingidae from the United States. Ohio Journal of Science 17:213-216.

Drake, C.J., AND J.D. LatTin. 1963. American species of the lacebug genus Acalypta (Hemiptera: Tingidae). Proceedings of the United States National Museum 115:331-345, 15 plates.

Drapolyuk, I.S. 1989. Species of the genus Myrmecophyes Fieb. (Heteroptera, Miridae) from the Caucasus. Entomological Review 68:90-100.

Franklin, J.F., and C.T. Dyrness. 1988. Natural vegetation of Oregon and Washington. Oregon State University Press. $452 \mathrm{pp}$.

Froeschner, R.C. 1976. Zoogeographic notes on the lacebug genus Acalypta Westwood in the Americas with description of a new species from Mexico (Hemiptera: Tingidae). American Midland Naturalist 96:257-269.

Golub, V.B. 1973. On the systematics of Palearctic lacebugs of the genus Acalypta Westw. (Heteroptera, Tingidae). Revue d'Entomologie de l'URSS 52:628-632. English translation in Entomological Review 52: 417-419.

Houghton, S.G. 1986. A trace of desert waters, the Great Basin story. Howe Brothers, Salt Lake City, UT. 287 pp.

KRAFT, G.F. 1960. Insects affecting bitterbrush and other range plants (final report). USDA Forest Service, Annual Report. Pacific Northwest Forest and Range Experiment Station. 56 pp.

LatTin, J.D. 1995. Hemiptera: Heteroptera of the Columbia River Basin, Western United States. Report prepared for the USDA, Forest Service. USDI Bureau of Land Management, Upper Columbia River Basin Ecosystem Management Project, Walla Walla, WA. 56 pp.
Scoloposcelis pulchella pulchella (Zetterstedt), in North America (Hemiptera: Heteroptera: Anthocoridae). Proceedings of the Entomological Society of Washington 107:729-730.

Lattin, J.D., A. Christie, And M.D. Schwartz. 1994. The impact of non-indigenous crested wheatgrasses on native blackgrass bugs in North America: a case for ecosystem management. Natural Areas Journal 14: 136-138.

. 1995. Native blackgrass bugs (Irbisia-Labops) on introduced wheatgrasses: commentary and annotated bibliography (Hemiptera: Heteroptera: Miridae). Proceedings of the Entomological Society of Washington 97: 90-111.

SChuH, R.T., AND J.D. LatTin. 1980. Myrmecophyes oregonensis, a new species of Halticini (Hemiptera: Miridae) from the western United States. American Museum of Natural History, Novitates 2697:1-11.

Scudder, G.G.E. 1997. True bugs (Heteroptera) of the Yukon. Pages 242-336 in H.V. Danks and J.A. Downes, editors, Insects of the Yukon. Biological Survey of Canada Monograph Series No. 2. 1034 pp.

SLATER, J.A. 1954. Notes on the genus Labops Burmeister in North America, with the description of three new species (Hemiptera: Miridae). Bulletin of the Brooklyn Entomological Society 49:57-65, 89-94.

Thorson, T.D., S.A. Bryce, D.A. Lammers, A.J. Woods, J.M. Omernik, J.M. Kaggan, D.E. Pater, and J.A. Comstock. 2003. Ecoregions of Oregon. U.S. Geological Survey Map, Reston, VA.

Received 11 February 2005 Accepted 27 May 2005 